\title{
A sportban alkalmazott alternatív táplálkozási formák Special diets and athletic performance
}

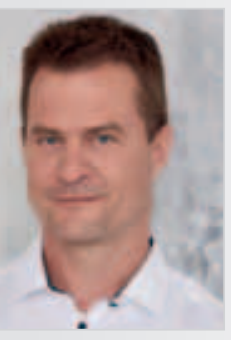

Szerzők/Authors: DR. HABIL. FRITZ PÉTER egyetemi docens/ PETER FRITZ DR. HABIL. associate professor Ferencvárosi Torna Club, Miskolci Egyetem E-mail:pfritz@hotmail.hu. Tudományos tevékenysége doktori iskolában témavezetố Scientific activity: supervisor in doctoral school Főbb kutatási terület: sporttáplálkozás, rekreáció Main areas of research: sports nutrition, recreation

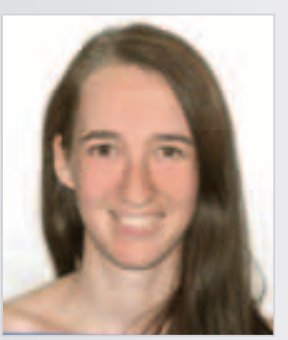

KISS ANNA/ANNA KISS Szent István Egyetem Élelmiszertudományi Kar Szent István University, Faculty of Food Science E-mail: kiss.anna891@gmail.com

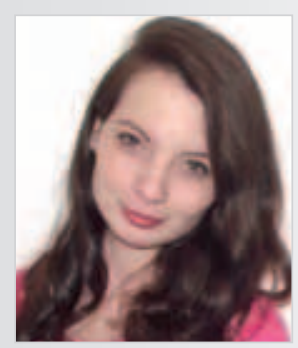

PFEIFFER LAURA/ LAURA PFEIFFER

Szent István Egyetem, Élelmiszertudományi Kar Szent István University, Faculty of Food Science E-mail:

laura.pfeiffer23@gmail.com

ÖSSZEFOGLALÁS: A sportolók a teljesítményük növelése és az egészségük megőrzése miatt elfogadják, és akár hosszú távon követik a különleges étrendeket, alternatív táplálkozási formákat. Napjainkban a négy, sportolók körében leggyakrabban alkalmazott étrend a gluténmentes, az alacsony FODMAP étrend, a vegetáriánus táplálkozás és az intermittáló koplalás. A sportolóknál a gluténmentes étrend tartása egyre népszerübb, megbízható prevalencia adatok azonban nincsenek, a nem-cöliákiás sportolók 41\%-a jelentette magáról, hogy gluténérzékeny. A gluténmentes étrend teljesítményre gyakorolt hatása napjainkban még nem tisztázott. Az alacsony fermentálható oligoszacharidok, diszacharidok, monoszacharidok és poliolok (FODMAP) bevitelén alapuló étrend az egyik lehetséges terápiás megközelítés az irritábilis bél szindrómában szenvedő betegeknél, a sportolók a nagymértékű fizikai aktivitással összefüggő gyomorbélrendszeri tünetek enyhítésére alkalmazzák. A vegetáriánus táplálkozás segíthet a megfelelő szénhidrátbevitel elérésében, a testtömegmenedzsmentben, továbbá gyenge, de pozitív összefüggést találtak a növényi étrend és a sportteljesítmény között. Az intermittáló koplalásban a böjtölési szakasz 16-20 órán át tart, amit 4-8 órás energiabeviteli időszak követ. A böjtölés ezen formája azonban ez idáig nem mutatott teljesítményfokozó hatást. Az alternatív táplálkozási formák nem megfelelő alkalmazása esetén szükségtelen táplálkozási korlátozásokkal járhatnak, ami miatt alaposan meg kell vizsgálni a sportoló által követni kívánt speciális étrend alapját és indikációját, valamint az étrendi korlátozás teljesítményre gyakorolt esetleges negatív hatásait.

Kulcsszavak: alacsony FODMAP, böjtölés, vegetarianizmus, teljesítmény

ABSTRACT: Athletes adopt special diets, alternative forms of nutrition to maintain their health and to improve their performance and they are even eager to follow them for a long period of time. Nowadays, among athletes, the four most commonly used diets are the gluten-free (GFD), the low FODMAP diet, the vegetarian nutrition and the intermittent fasting. Keeping a gluten-free diet has become more populare among athletes, however there are no reliable prevalence data, forty-one percent of non-celiac athletes reported themselves having gluten-intolerance. Nowadays, the effect of gluten-free diet on performance is not clear yet. Nutrition based on taking low fermentable oligo-, di-, monosaccharides and polyols (FODMAP) is one of the possible therapeutic approaches on patients with irritable bowel syndrome. Athletes are using this diet to relieve gastrointestinal symptoms associated with high physical activites. Vegetarian nutrition can help to achieve proper carbohydrate intake, body weight management, furthermore they found a weak but positive relationship between plantbased diet and sports performance. In the intermittent fasting, the fasting period lasts for 16-20 hours, it is followed by a 4-8 hour long energy intake period. However, this form of fasting has not shown any performance enhancing effect so far. Inappropriate use of alternative forms of nutrition may lead to unnecessary dietary restrictions, which should carefully examine the basis and indication of the specific diet that the athlete intends to follow and the potential negative effects of dietary restriction on performance.

Keywords: low FODMAP, fasting, vegetarian, performance

\section{A sportban alkalmazott alternatív táplálkozási formák}

Egyre több sportoló követ speciális étrendet az egészség fenntartása és/vagy a teljesítmény növelése érdekében. A gluténmentes, a vegetáriánus és az intermittáló koplalás az egészség, az etika, a vallás és a teljesítmény szempontjából a legelterjedtebb étrendek közé tartoznak.

Ezek az étrendek, divatirányzatok azonban szükségtelen étrendi korlátozásokkal járó kockázatokkal járhatnak, nem megfelelő alkalmazásuk esetén potenciálisan több kárt okozhatnak, mint hasznot.

Az étrendi kockázatok minimalizálása érdekében a sportoló által követett étrendnek a bizonyítékokon alapuló megközelítése ajánlott (Lis et al., 2019). Négy, sportolók által is követett étrendet mutatunk be jelen tanulmányban: (1) gluténmentes, (2) alacsony FODMAP (fermentálható oligo-, di-, monoszacharidok és poliolok), (3) vegetáriánus, (4) az intermittáló koplalás. Napjainkban a gluténmentes étrendet és az alacsony FODMAP-étrendet olyan új étrendi megközelítésnek tekintik, amelyekről úgy gondolják, hogy javítják a gyomor-bélrendszer egészségét, és csökkentik a gyomor-bélrendszeri bántalmak kialakulásának kockázatát.

A sportolókról szóló megfigyelések azt sugallják, hogy az élelmiszer-intolerancia a körükben egyre nő, de számos olyan tényező, mint például a nem validált élelmiszer-intolerancia vizsgálat és az öndiagnosztizáláson alapuló, jelentett esetek előfordulási gyakorisága a valódi intolerancia pontos becsléseit nehezíti meg (Kostic-Vucicevic et al., 2016). 


\section{Vegetáriánus táplálkozás}

A vegetáriánus táplálkozás világszerte egyre több követőre talál. A vegetáriánusok és a vegán étrendet követők száma évről évre nő, az Európai Unióban Németország után Olaszországban és Svájcban a legnagyobb a vegetáriánus táplálkozást folytatók aránya. Hazánkban sajnos nem állnak rendelkezésre az alternatív táplálkozást követők arányára vonatkozó nyilvános adatok. Németországban 1983-ban a lakosság mindössze 0,6\%-a volt vegetáriánus, 2014-ben pedig a lakosság közel 10\%-a követte e táplálkozási trendet. A vegetáriánus étrendet követők száma 20 éven belül több mint a tízszeresére nőtt. Napjainkban 7,8 millió vegetáriánus és 900000 szigorúan vegetáriánus táplálkozást folytató él Németországban (Schwink, 2014).

A sportolók vegetáriánus és vegán étrendet alkalmaznak egészségi, etikai, környezeti, vallási/lelki és esztétikai okokból. Míg a sportolók körében a növényi táplálkozás iránti érdeklődés nem újkeletű, népszerüsége, különösen a vegán étrend és a szemi-vegetáriánus vagy a flexitáriánus étrend esetében a jelenlegi nyilvános trendek változatossága mellett növekszik (Meyer és Reguant-Closa, 2017). A sportolók körében a vegetarianizmus előfordulási aránya nem teljesen ismert, de feltételezhető, hogy hasonló az általános népességhez. Az élsportolók körében készült egyetlen, prevalenciát felmérő tanulmány szerint a nemzetközi sportolók 8\%-a vegetáriánus étrendet követett; 1\%-uk vegán (Pelly \& Burkhart, 2014).

Sok sportoló a növényi alapú étrendet az egészségre gyakorolt pozitív hatása miatt választja, azonban követését a sportteljesítmény szempontjából is előnyösnek gondolják. A vegetáriánus táplálkozás segíthet a megfelelő szénhidrátbevitel elérésében, a testtömegmenedzsmentben és a fizikai teljesítmény növelésében. Feltételezték, hogy a növényi alapú étrend növeli és segíti az izom glikogénszint-megőrzését, erősíti az immunrendszert, és csökkenti az oxidatív stresszt, hozzájárulva ezáltal a sportteljesítmény növeléséhez. A randomizált kontroll és keresztmetszeti kutatások eredményei e hipotézisek teljesülését nem támasztották alá, habár egyes kutatások eredményei gyenge, de pozitív összefüggést találtak a növényi étrend és a sportteljesítmény egyes mutatói között.

\section{A vegetáriánus \\ táplálkozás formái}

A növényi alapú táplálkozásnak több formája ismert, amelyekkel fontos tisztában lenni, hiszen mindegyiknél más élelmiszerek fogyasztása megengedett, valamint más-más rizikófaktorokkal kell számolnunk sporttáplálkozás szempontjából. A legfrissebb adatok szerint a vegetáriánus táplálkozási irányzatoknak hat formája különböztethető meg, valamennyi vegetáriánus étrendi típusra jellemző, hogy vörös húsokat (sertés-, marha-, borjúhús) és belőlük készülő élelmiszereket kizárják az étrendből. A szemi-lakto-ovo vegetáriánusok étrendje vörös húsokat és szárnyasokat nem tartalmaz, azonban halat, tojást és tejtermékeket fogyasztanak. A lakto-ovo-vegetáriánus irányzatot követőknél a tej, tejtermék fogyasztásán túl tojást is szerepeltet étrendjükben. A lakto-vegetáriánusok a növényi eredetű táplálékok mellett tejet és tejtermékeket fogyasztanak. Az ovo-vegetáriánus étrendjében a tojás szerepelhet, a szemi-vegetáriánusok asztalára pedig időnként hal kerül. A vegán irányzatot követők kizárólag növényi eredetű termékekből állítják össze étrendjüket (Ledochowski, 2010). A növényi étrendre jellemző, hogy gazdag oligo- és polszaharidokban, rostokban, zöldségekben és gyümölcsökben, antioxidánsokban és fitokemikáliákban, valamint telített zsírsav és koleszterin tartalma kicsi (Venderleyn \& Campbell, 2006).

\section{A növényi étrend követése során felmerülő kihívások a sportolók körében}

Több világklasszis sportoló, mint például a nehézsúlyú boxoló David Haye, a teniszbajnok Venus Williams vagy a többszörös Forma 1-es világbajnok Lewis Hamilton is beszámoltak már a nyilvánosság előtt arról, hogy vegetáriánus vagy vegán táplálkozást folytatnak. A növényi alapú táplálkozást rengeteg kritika és negatív vélemény övezi, a vegán sportolók esetében táplálkozási kihívásokkal kell szembenéznünk, mikor étrendet állítunk össze számukra.

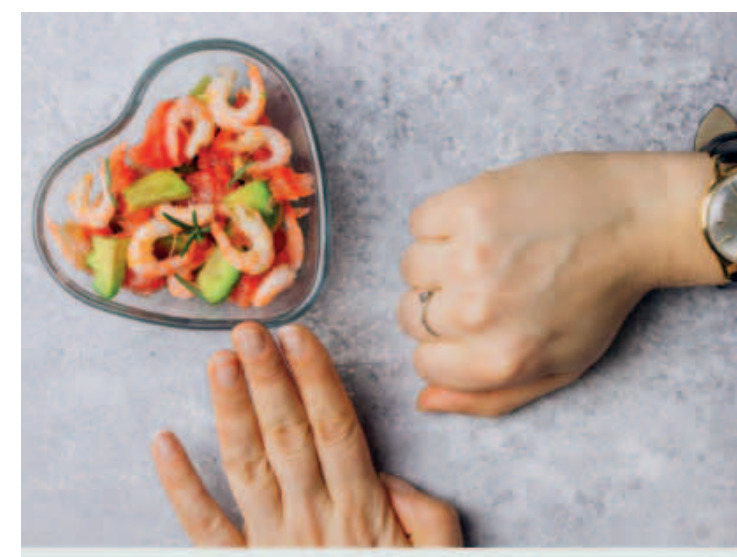

A Német Táplálkozási Társaság (DGE) az aktuális, tudományos szakirodalom alapján a vegetáriánus táplálkozásra vonatkozó állásfoglalást hozott nyilvánosságra. A DGE megállapítása szerint a referenciaértékeknek megfelelő tápanyagbevitel kizárólag vegyes, változatos élelmiszerválasztás esetén érhető el. Mivel a vegetáriánus étrendet követők az állati eredetű élelmiszerek fogyasztásáról lemondanak, egyes tápanyagok bevitele hiányos lehet. A sportolók számára tervezett étrend összeállításakor az első kihívások a megfelelő energiabevitel biztosítása, mert a csak növényekből álló étrend tápanyagsűrüsége általában kisebb, mint a vegyes étrendé. A makrotápanyagok közül a fehérjebevitel, ezen belül az esszenciális aminosavak bevitele jelenthet kihívást, ezen fehérjék egy-két esszenciális aminosavból kevesebbet tartalmaznak, ezért a növényi fehérjék biológiai értéke kisebb.

Kritikus mikrotápanyag a $\mathrm{B}_{12}$-vitamin, ezért a vegetáriánusoknak a megfelelő $\mathrm{B}_{12}$-vitamin-ellátottság érdekében rendszeres orvosi ellenőrzés és $\mathrm{B}_{12}$-vitamint tartalmazó étrend-kiegészítő fogyasztása szükséges. A DGE ezen túl funkcionális- és dúsított élelmiszerek fogyasztását ajánlja a tápanyaghiány elkerülése miatt. A szakértők potenciálisan kritikus tápanyaghoz sorolják továbbá az esszenciális aminosavakat, az omega-3-zsírsavat, valamint a D-vitamint, a riboflavint, a kalciumot, a jódot, a vasat, a cinket és a szelént. A szigorúan vegetáriánus étrend több tápanyag (fehérje, vas, cink, kalcium, riboflavin, piridoxin, kobalamin, kalciferol) vonatkozásában is elégtelen bevitelt jelentenek az energiahiányos táplálkozás mellett (Schwink, 2014).

Időszakosan a béta-alanin és kreatin kiegészítés is javasolt lehet abban az esetben, ha az izom kreatin- és karnozinszintje elégtelen a sportolónak 
(Rogerson, 2017). Ezen problémák áthidalására született meg egy 2017es irodalmi áttekintés, mely segítséget nyújt abban, hogy elérjük a szükséges tápanyagok megfelelő mennyiségét és minőségét sportolók esetében.

A zöldségek, gyümölcsök, szárazhüvelyesek, olajos magvak és teljes őrlésű lisztből készült termékek a vegetáriánus étrendet követők által gyakran fogyasztott élelmiszerek. A német helyzetfelmérés megállapítja, hogy a vegetáriánus étrendben fogyasztott élelmiszerek nem minden esetben kedvezők és egészségvédők táplálkozás-élettani szempontból. Ez abban az esetben igaz, ha a vegetáriánusok számára gyártott élelmiszerek hozzáadott cukor-, zsír- és konyhasótartalommal készülnek/ rendelkeznek.

A sportolók körében fellépő, a növényi alapú étrendhez kapcsolódó lehetséges táplálkozási problémákat az 1. táblázat mutatja be.

\section{Összefoglalás}

Az alternatív étrendek alkalmasak lehetnek egyes, étrendi szükséglet szempontjából különleges helyzetben lévő sportolók számára, de alkalmazásuk előtt alaposan meg kell vizsgálni az étrend kiválasztásának alapját. A speciális étrendhez való ad hoc ragaszkodás számos kockázattal jár, amelyeket rendszeresen monitorozni kell.

Speciális étrend esetén a megfelelő oktatás alapvető fontosságú, mivel az étrendi korlátozás több kárt okozhat, mint hasznot. Az élvonalbeli teljesítménymutatók növelése érdekében a táplálkozás optimalizálását megfelelő végzettséggel rendelkező táplálkozástudományi szakember és megfelelő egészségügyi és sporttudományi személyzet tanácsával együttesen kell alkalmazni és a speciális étrend betartása előtt felkeresni.

\section{Irodalomjegyzék}

Costa, R. J. S., Snipe, R. M. J., Kitic, C. M., \& Gibson, P. R. (2017). Systematic review: Exercise-induced gastrointestinal syndrome-implications for health and intestinal disease. Alimentary Pharmacology \& Therapeutics, 46(3), 246-265.

El-Salhy, M. \& Gundersen, D. (2015). Diet in irritable bowel syndrome. Nutrition journal, 14(1), 36.

\section{1. táblázat: A növényi alapú étrend típusaihoz kapcsolódó lehetséges táplálkozási problémák sportolók körében}

\begin{tabular}{|c|c|c|}
\hline Étrend típusa & $\begin{array}{l}\text { Lehetséges étrendi } \\
\text { problémák }\end{array}$ & $\begin{array}{l}\text { Lehetséges } \\
\text { sporttáplálkozáshoz } \\
\text { kapcsolódó problémák }\end{array}$ \\
\hline Vegyes táplálkozás & $\begin{array}{l}\text { Az egyoldalú, nem változatos étrend } \\
\text { egyes tápanyagok hiányához vezethet } \\
\text { (pl. D-vitamin-hiány). }\end{array}$ & $\begin{array}{l}\text { Mind a férfi és mind a női sportolók } \\
\text { körében a kis energiabevitel } \\
\text { tápanyaghiányhoz vezethet. A negatív } \\
\text { egyensúlyi állapotokban a kalciumigény } \\
\text { növekszik, valamint menstruációs zavar } \\
\text { és női atléta triász is felléphet. }\end{array}$ \\
\hline Szemi-vegetáriánus & $\begin{array}{l}\text { Ugyanaz, mint a vegyes táplálkozás } \\
\text { esetében, továbbá energia és fehérje } \\
\text { hiány is felléphet. }\end{array}$ & $\begin{array}{l}\text { Vashiány kialakulásának kockázata áll } \\
\text { fenn női sportolóknál. }\end{array}$ \\
\hline $\begin{array}{l}\text { Lakto-ovo/lakto- } \\
\text { vegetáriánus }\end{array}$ & $\begin{array}{l}\text { Ugyanaz, mint a szemi-vegetáriánusok } \\
\text { esetében, továbbá omega-3-zsirsav } \\
\text { (DHA, EPA), vas, cink, riboflavin hiány } \\
\text { is felléphet. }\end{array}$ & $\begin{array}{l}\text { Ugyanaz, mint a szemi-vegetáriánusok } \\
\text { esetében, valamint csökkent kreatin- és } \\
\text { karnozinszint az izomban mindkét nem } \\
\text { esetében. }\end{array}$ \\
\hline Vegán & $\begin{array}{l}\text { Ugyanaz, mint a vegetáriánusok, } \\
\text { továbbá fehérje, zsír (omega-3- } \\
\text { zsírsav), } \text { B12-vitamin, kalcium, jód hiány }_{\text {mindkét nem esetében. }}\end{array}$ & $\begin{array}{l}\text { Ugyanaz, mint a vegetáriánusoknál, } \\
\text { továbbá: alacsony csontsürüség női } \\
\text { sportolóknál, energiaegyensúly } \\
\text { elérésének problémája. }\end{array}$ \\
\hline
\end{tabular}

Forrás: Rogerson, 2017 alapján

Gaskell, S. K., \& Costa, R. J. S. (2018). Applying a Low-FODMAP Dietary Intervention to a Female Ultra-Endurance Runner With Irritable Bowel Syndrome During a Multi-Stage Ultra-Marathon. International Journal of Sport Nutrition and Exercise Metabolism, 10.1123/ijsnem.2017-0398, 1-19.

Kostic-Vucicevic, M., Marinkovi, D., Dikic, N., et al. (2016). Is there connection between food intolerance and sports performance in elite athletes? British Journal of Sports Medicine, 10.1136/bjsports-2016-097120.35, A20.21-A20.

Ledochowski, M. (Hrsg.) (2010). Klinische Ernährungsmedizin. Wien: Springer.

Lis, D. M., Kings, D., \& Larson-Meyer, D. E. (2019). Dietary practices adopted by track-and-field athletes: Gluten-free, low FODMAP, vegetarian, and fasting. International journal of sport nutrition and exercise metabolism, (00), 1-10.

Lis, D., Stellingwerff, T., Kitic, C. M., Ahuja, K. D., \& Fell, J. (2015). No effects of a short-term gluten-free diet on performance in non-celiac athletes. Medicine \& Science in Sports \& Exercise, 47(12), 2563-2570.

Lis, D., Stellingwerff, T., Shing, C. M., Ahuja, K., DK, \& Fell, J. (2015). Exploring the popularity, experiences, and beliefs surrounding gluten-free diets in nonceliac athletes. International Journal of Sport Nutrition and Exercise Metabolism, 25, $37-45$.
Lis, D., Stellingwerff, T., Kitic, C. M., Fell, J. W., \& Ahuja, K. D. K. (2017). Low FODMAP: A Preliminary Strategy to Reduce Gastrointestinal Distress in Athletes. Medicine \& Science in Sports \& Exercise, $50(1), 116-123$.

Maughan, R. J., Fallah, J., \& Coyle, E. F. (2010). The effects of fasting on metabolism and performance. British Journal of Sports Medicine, 44(7), 490-494.

Morton, J., Stellingwerff, T., \& Burke, L. M. (2018). Periodised nutrition for training adaptation. International Journal of Sport Nutrition and Exercise Metabolism, in press.

Rogerson D. (2017). Vegan diets: Practical Advice for Athletes and Exercisers. Journal of the International Society of Sports Nutrition. 14,36. doi: 10.1186/ s12970-0192-9

Tinsley, G., Forsse, J., Butler, N., Paoli, A., \& Bane, A. (2017). Time-restricted feeding in young men performing resistance training: A randomized controlled trial. European Journal of Sport Science, 17(2), 200-207.

Schwink, A. (2014). Vegane Ernährung. Ernährungs Umschau, 6: 23-26.

Venderley, A.M., \& Campbell, W.W. (2006). Vegetarian diets: Nutritional considerations for athletes. Sports Medicine (Auckland, N.Z.), 36(4), 293-305. PubMed doi:10.2165/00007256-20063604000002 